\title{
Strategy To Achieve Birth Certificate Ownership In Kalisidi Village, West Ungaran Sub-District
}

\author{
Tri Wida Yanti, Arief Sadjiarto* \& Destri Sambara Sitorus \\ Economic Education, Faculty of Teacher Training and Education, \\ Universitas Kristen Satya Wacana, Indonesia
}

Received: 14 May 2020; Reviewed: 13 June 2020; Accepted: 21 February 2021

* Email Coresponding: arief.sadjiarto@uksw.edu

\begin{abstract}
This study aims to determine the strategy of the village government in optimizing the achievement of ownership of birth cerificates with a focus on the management function and strategy management. This study used descriptive qualitative method. The research instrument was the researcher itself using primary and secondary data sources. Data collection techniques used were observation, interviews and documentation. The strategy of the Kalisidi village government was based more on management functions (planning, organizing, directing and controlling) and supported by strategic management. Planning started with regional mapping, team planning, team preparation planning, socialization planning and evaluation planning. Organizing was done by forming a team of hamlet and RT heads as the person in charge of the hamlet and the administrative staff as the village coordinator. Directing and controlling the team did not experience difficulties because each team had done the activity well. The obstacle of analyzing the external environment were the distance and the people's livelihood. Through this combination can produce solutions and solutions for the implementation of further activities.
\end{abstract}

Keywords: Strategy; Birth Certificate.

How to Cite: Yanti, T.W., Sadjiarto, A., \& Sitorus, D.S., (2021). Strategies to Achieve Birth Certificate Ownership in Kalisidi Village, West Ungaran Sub- District. Jurnal Administrasi Publik (Public Administration Journal), 11(1): 1-10. 


\section{INTRODUCTION}

Administrative services are services provided by the providers of various types of documents used by the public. Based on (Maksudi, 2017) the role of public administration includes 1) basic government 2) tools for providing services to the community 3 ) tools for implementing policies made by the government 4) the power of stability in society 5) tools for carrying out economic development and social improvement 6) technical characteristics where the government provides the services to the population. The scope of village administration includes population administration, general administration, financial administration and other administration. Based on (Bailah, 2019) village government administration is the whole process of activities regarding the recording information and data about village government which can be seen in the village register book. In village administration, population administration is one of the most important aspects. Population administration is a series of all administrative activities that cover the issuance of documents through registration, data collection and document processing which is one of the results of public services.(Jarnawansyah, 2019). Population documents are official documents issued by government agencies. In Law No. 23 Article 59 of 2006 population documents consist of: 1) resident bio 2) family card 3) identity card 4) residence certificate 5) civil registration certificate. A civil registration certificate is valid for life, which contains an important event of a person. An example of a civil registration certificate is a birth certificate. A birth certificate is a document in the form of a certificate issued by the local Population and Civil Registration Service(Ramadan et al, 2019). A birth certificate is one of the important documents that every Indonesian citizen must have. The benefits of having a birth certificate are: 1) a person's status is recognized by the state 2) a valid document about a person 3) a requirement for entry into the world of education and work 4) as a condition for making ID Card, family card and ID card number. The benefits of a birth certificate for child who is not yet 18 years old, a birth certificate can be used as a valid proof of identity.

In $2016,61,823$ people in Semarang Regency did not have birth certificates for children aged 0-18 years. The Department of Population and Civil Registration of Semarang Regency revealed that "the number of children aged 0-18 years in Semarang Regency was recorded as $312,594,250,771$ people already had birth certificates in 2016, so there are still 61,823 people who do not have birth certificates" (kompas.com, Monday 9 January 2017).

Kalisidi Village is a fairly large area in West Ungaran Subdistrict with a geographical location that is dominated by hills and highlands. Kalisidi Village has an area of 792,609 hectares, a population of 6,637 with a family card of 2,105 . The residential area of Kalisidi Village is at certain points and scattered, in achieving the ownership of a birth certificate, Kalisidi Village is able to reach the top 3 of 11 villages in West Ungaran Subdistrict, it can be seen from the acquisition of a presentasse of $53.20 \%$, but still there are $46.80 \%$ of the population do not have a birth certificate.

The reasons for the residents of Kalisidi Village do not have a birth certificate are 1) for the population of children or toddlers, their parents are ashamed to register because the age range of births with marriage is very short and there is also a betel or extramarital marriage 2) for elder residents or adults consider that birth certificates are less important because their age is no longer productive for work. The reality of having a birth certificate is not in line with government program priorities related to orderly population administration. In 
maximizing ownership of birth certificates, a village government strategy is needed.

Based on (Sedarmayanti, 2014) strategic concepts include Distinctive Competence and Competitive Advantage. Distinctive Competence is an action taken by an organization to carry out the activities better than its competitors, while Competitive Advantage is a strategy by the organization to seize existing opportunities. Based on(Fahmi, 2014) the scope of strategic management is: 1) analyzing the impact of the application of strategic management to the internal organization 2) placing an understanding of strategic management as the basis for the organization to make decisions 3) strategic management science is used as the basis of science in building plans that have been prepared.

Based on the description above, the researcher is interested in conducting research on the Strategy for Achieving Birth Certificate Ownership in Kalisidi Village, West Ungaran Subdistrict, with the formulation of the problem, how the strategy is implemented by the Kalisidi Village government in an effort to achieve birth certificate ownership in Kalisidi Village. The objective is to find out the strategies implemented by the Kalisidi Village government in an effort to achieve ownership of a birth certificate in Kalisidi Village.

\section{RESEARCH METHOD}

This study is a qualitative descriptive study in order to obtain an in-depth description of the village government strategy in achieving birth certificates. This study was conducted in Kalisidi Village, West Ungaran Subdistrict, Semarang Regency. Research instruments and tools were the researchers themselves. As a human instrument, researchers function in determining research, selecting informants used as data sources, collecting data, measuring data quality, interpreting data and making conclusions from the findings.
In this study, researchers used primary data sources and secondary data sources. The primary data sources in this study were the Village Head, Village Apparatus and population, while the secondary data sources were data from the Department of Population and Civil Registration (Disdukcapil), newspapers, the internet and so on. The data collection techniques used were observation, interview and documentation.

\section{RESULTS AND DISCUSSION}

The efforts to optimize the ownership of a birth certificate in Kalisidi Village began with the socialization of the program received by the Kalisidi Village Government provided by the Semarang Regency Department of Population and Civil Registration in 2017. After socialization, the Kalisidi Village Government determined a strategy with initial steps to determine the parties to be involved, after determining the parties who involved and then carried out the socialization of an orderly population administration program and civil registration which includes: 1 ) The importance of orderly population administration and civil registration 2) Provisions for file equipment based on caseistics that underlie birth certificates (missing, damaged, or never made or based on age level namely newborns, children and adolescents, adults and age above birth before 1974) 3) The role and function of the Village Government in the birth certificate process. 4) Procedures and flow of the birth certificate process.

Socialization to the community was carried out by Kalisidi Village Government and the team through two media, namely oral and written. Oral socialization was delivered at routine events held in the Neighborhood Association to hamlet community such as Quranic recitation (tahlilan), social gathering, association of empowerment and family welfare, usual recitation and nyadran events. The written socialization was delivered through 
brochures and pamphlets. Media brochures were given to people attending the event while pamphlets were posted in strategic places.

Intensive socialization had been carried out since the existence of an orderly population administration and civil registration program. However, the program was only responded by people who had just given birth. The low response of the people who did not have a birth certificate which was compared to the high response of making birth certificates for newborns by Kalisidi Village people were like two opposing magnetic poles. This condition was then evaluated by encouraging the community to be able to take the time to make birth certificates for those who have not made birth certificates. In 2018 Kalisidi Village was appointed as Gisa Village in West Ungaran Sub district. Desa GISA (Gerakan Indonesia Sadar Adminduk) was a national movement from the government to increase public awareness of the importance of population documents, in the election of GISA Village, only one district was selected through GISA Village. It was expected that people who already have a birth certificate were 99\% $100 \%$. The following table shows the number of birth certificate ownership by age:

Table 1. Number of Birth Certificate Ownership by Age

\begin{tabular}{|c|c|c|c|c|c|c|c|c|c|c|c|c|c|c|c|c|}
\hline 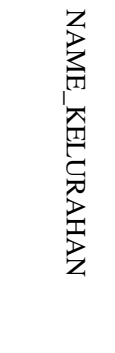 & 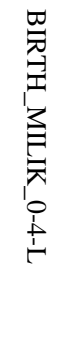 & 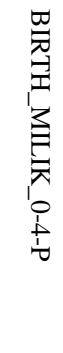 & 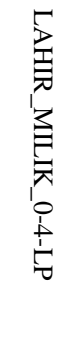 & 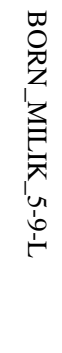 & 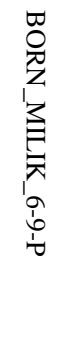 & 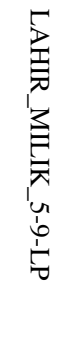 & 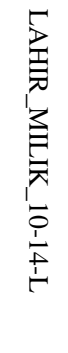 & 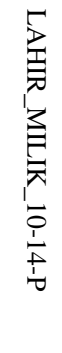 & 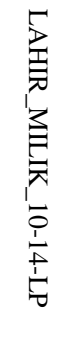 & 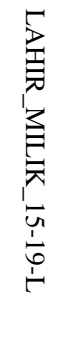 & 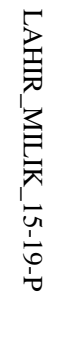 & 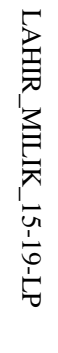 & 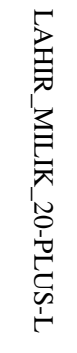 & 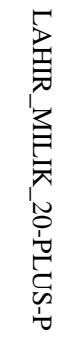 & 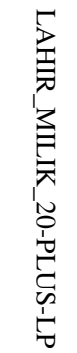 & 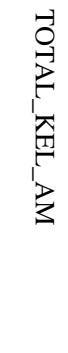 \\
\hline $\begin{array}{l}\text { CANDI } \\
\text { REJO }\end{array}$ & 194 & 199 & 393 & 214 & 205 & 419 & 175 & 189 & 364 & 143 & 133 & 276 & 547 & 484 & 1031 & 2483 \\
\hline GENUK & 279 & 260 & 539 & 277 & 292 & 569 & 251 & 244 & 495 & 195 & 192 & 387 & 907 & 871 & 1778 & 3768 \\
\hline $\begin{array}{l}\text { BUDGE } \\
\mathrm{T}\end{array}$ & 346 & 362 & 708 & 390 & 405 & 795 & 362 & 318 & 680 & 290 & 263 & 553 & 1379 & 1417 & 2796 & 5532 \\
\hline $\begin{array}{l}\text { BAND } \\
\text { ARJO }\end{array}$ & 344 & 299 & 643 & 383 & 364 & 747 & 333 & 311 & 644 & 265 & 226 & 491 & 1216 & 1172 & 2388 & 4913 \\
\hline $\begin{array}{l}\text { LANGE } \\
\text { NSARI }\end{array}$ & 315 & 314 & 629 & 395 & 381 & 776 & 338 & 359 & 697 & 281 & 297 & 578 & 1150 & 1041 & 2191 & 4871 \\
\hline $\begin{array}{l}\text { BRANJ } \\
\text { ANG }\end{array}$ & 116 & 97 & 213 & 139 & 131 & 270 & 102 & 121 & 223 & 97 & 98 & 195 & 289 & 245 & 534 & 1435 \\
\hline $\begin{array}{l}\text { KALISI } \\
\text { DI }\end{array}$ & 249 & 242 & 491 & 289 & 280 & 569 & 223 & 243 & 466 & 173 & 184 & 357 & 785 & 642 & 1427 & 3310 \\
\hline $\begin{array}{l}\text { VIOLE } \\
\text { NT }\end{array}$ & 92 & 78 & 170 & 84 & 102 & 186 & 80 & 92 & 172 & 66 & 77 & 143 & 300 & 285 & 585 & 1256 \\
\hline LEREP & 477 & 414 & 891 & 534 & 486 & 1020 & 405 & 375 & 780 & 235 & 237 & 472 & 916 & 811 & 1727 & 4890 \\
\hline $\begin{array}{l}\text { NYATN } \\
\text { YONO }\end{array}$ & 337 & 288 & 625 & 451 & 405 & 856 & 297 & 322 & 619 & 184 & 173 & 357 & 625 & 549 & 1174 & 3631 \\
\hline GOGIK & 170 & 124 & 294 & 157 & 164 & 321 & 128 & 134 & 262 & 112 & 102 & 214 & 522 & 419 & 941 & 2032 \\
\hline
\end{tabular}

Source: Department of Population and Civil Registration of Semarang Regency, 2018

In January 2019, Kalisidi Village Government collaborated with the Semarang Regency Disdukcapil Office to hold mass deeds at the Kalisidi Village Hall to support and motivate the community to apply for the birth certificates. The process of making a mass deed was the same as making an independent one, namely by bringing the necessary administrative requirements. The number of people who participated in the submission of mass deeds was 44 people, while 42 people passed the administrative selection. After the mass deeds were made, the public response was getting better. The following table shows the number of birth certificate ownership based on the sub-district level in West Ungaran District: 
Table 2. Total Ownership of Birth Certificates by District Level in West Ungaran District

\begin{tabular}{|c|c|c|c|c|c|}
\hline \multicolumn{6}{|c|}{ Regency / City: 33.22 SEMARANG } \\
\hline & & District: $33.22 .18 \mathrm{UN}$ & ARAN BARA & & \\
\hline \multirow[b]{2}{*}{ No. } & \multicolumn{2}{|r|}{ Village / Sub-district } & \multirow[b]{2}{*}{$\begin{array}{c}\text { Total } \\
\text { population }\end{array}$} & \multirow{2}{*}{$\begin{array}{l}\text { Number of } \\
\text { Birth } \\
\text { Certificate } \\
\text { Ownership }\end{array}$} & \multirow[b]{2}{*}{ \% Ownership } \\
\hline & Code & Name & & & \\
\hline 1 & 1006 & CANDIREJO & 4,845 & 2,564 & $52.92 \%$ \\
\hline 2 & 1007 & GENUK & 7,604 & 3,914 & $51.47 \%$ \\
\hline 3 & 1008 & BUDGET & 11,149 & 5,779 & $51.83 \%$ \\
\hline 4 & 1009 & BANDARJO & 9,734 & 5,119 & $52.59 \%$ \\
\hline 5 & 1010 & LANGENSARI & 9,239 & 5,053 & $54.69 \%$ \\
\hline 6 & 2001 & BRANJANG & 3,333 & 1,496 & $44.69 \%$ \\
\hline 7 & 2002 & KALISIDI & 6,461 & $\mathbf{3 , 4 3 7}$ & $53.20 \%$ \\
\hline 8 & 2003 & VIOLENT & 2,505 & 1,294 & $51.66 \%$ \\
\hline 9 & 2004 & LEREP & 11,843 & 5,119 & $43.22 \%$ \\
\hline 10 & 2005 & NYATNYONO & 8,338 & 3.25 & $45.87 \%$ \\
\hline \multirow[t]{3}{*}{11} & 2011 & GOGIK & 3,824 & 2,097 & $54.84 \%$ \\
\hline & & Total & 78,875 & 39,697 & $50.33 \%$ \\
\hline & & Total number & 78,875 & 39,697 & $50.33 \%$ \\
\hline
\end{tabular}

Source: Department of Population and Civil Registration of Semarang Regency, 2019

Based on table 2, it can be seen that there is an increase in 2018 to 2019 of $1.97 \%$.

In 2019, the process of making birth certificates was slightly hampered due to regional and national elections. In 2020 the program started running again and there was a change in the process of making a birth certificate. The community no longer needed to come directly to the Department of Population and Civil Registration of Semarang Regency, but simply submitted the complete data file to the Kalisidi Village Office which would then be registered online by the Kalisidi Village official Staff to the Department of Population and Civil Registration link via the Smard application.

Making birth certificates was made easier by simply delivering the documents to the village official or the head of the local Neighborhood Association which was then taken to the Kalisidi Village Office. The ease in making birth certificates has resulted in this result. It can be seen that in early February 2020 to mid March 2020 there were 107 residents who applied for birth certificates. Not all applications were accepted because there were several applicants who were rejected because the files were incomplete. The following is the tabulation of Kalisidi Village people who submitted a birth certificate for the period February 2020 to March 2020.

Table 3. Tabulation of Application for Birth Certificate in Kalisidi Village, 2020

\begin{tabular}{llll}
\hline & Man & Women & Total \\
\hline Finish certificate & 34 & 43 & 77 \\
\hline On process & 13 & 11 & 24 \\
\hline Rejected & $\mathbf{2}$ & 4 & 6 \\
\hline Total & 49 & 58 & 107 \\
\hline
\end{tabular}

The finished certificate was evidence of population administration and civil registration that was first owned by an Indonesian citizen. But in reality, not all citizens have birth certificates. Generating the community enthusiasm in making birth certificates was not simple. The elder people (parents) thought that a birth certificate was not important, so a strategy was needed so that all levels of society were aware of the importance of having a birth certificate.

Strategy is the science and art that is used in preparing an activity plan regarding policies or activities that will be carried out by utilizing all resources within a certain time and size to achieve predetermined goals (Nippi \& M, nd, 2019). In a strategy, activities cannot be separated from the planning arrangement for its resources. The notion of strategy has almost the same 
meaning with the notion of management based on Terry and Rue in (Sundari, 2011)interpreted as a work implementation technique that includes direction from a group of people who lead to organizational goals in the real activities. Management is an activity, its implementation is called management, while the executor is the manager.

Prior to carrying out the socialization, the Kalisidi Village Administration Staff had planned a program to optimize the ownership of a birth certificate in Kalisidi Village. Kalisidi Village Government strategic planning related to optimization of birth certificate ownership discussed the mapping of areas based on hamlet territory, the formation of a team consisting of parties who will be involved in the optimization program of birth certificate ownership, planning team preparation, socialization strategies to residents, and evaluation plans.

The planning carried out by the Kalisidi Village Administration Staff above based on the researcher was a complete plan. The point is that planning is not only as long as the program is running, but also wants to actually implement the program to achieve the desired goals. It can be seen from the existence of an area mapping plan, a plan for the parties involved as well as a program implementation and evaluation plan.

Based on Hasibuan (2005) planning is the basic role of management, because in carrying out organizational activities, staffing, direction and control must be planned in advance. Planning is dynamic in nature and is used to set goals and the best techniques for achieving goals in a number of ways. Through planning, the Kalisidi Village Administration Staff could find out what activities would be carried out to achieve predetermined goals.

Based on Hasibuan's opinion, the planning from the Kalisidi Village Administration Staff was clearly aimed at making the next management elements run optimally. Based on the researchers, the planning of the parties involved was ideal and can support the organizing element. The existence of community leaders which was also supported by the regional mapping was an important element. An understanding of the scope of village government performance and the familiarity of the parties involved with the village government were good consideration. The existence of community leaders will certainly facilitate communication and community acceptance.

"Without a description of the design of the activities that will and must be carried out, of course the program to optimize the birth certificate ownership will run carelessly and will be prone to failure. However, with an overview of the activity design, our team will be able to prepare and finalize the strategy so that it runs according to the description during planning "(Mr. Imroni, Kalisidi Village Administration Staff).

What was stated by the Kalisidi Village Administration Staff, Mr. Imroni, is in line with the opinionTerry (2014) which states that in describing and formulating the proposed activities it is necessary to achieve the desired results.

The management function after planning is organizing. Wiludjeng (2007) revealed that organizing is an activity in seeking practical interaction between people, so that they can work together efficiently with it so that they can gain personal satisfaction in carrying out certain tasks in certain conditions in order to obtain the desired goals and objectives. In organizing, the Kalisidi Village Administration Staff forming a team by involving parties that are directly related to the community in accordance with the mapping of the area based on the rural aspects. The Hamlet Head was in charge, all Heads of Neighborhood Associations and religious leaders were as the socialization team and Kalisidi Village Administration Staff were as 
the village coordinator and concurrentlyas an IT team.

The organizing carried out by the Kalisidi Village Administration Staff had met the organizing standard. The formal structure had been composed of the person in charge of the center to those who have direct contact with the community who are related to the socialization process. It is in accordance with the organizing implementation as stated by(Handoko, 2014) that organizing is an activity that is used to organize and classify the tasks of each member of the organization, as well as designing the organizational structure so that the goals of each organization can be achieved efficiently as well as the opinions of(Sillalahi, 2011). In order to obtain the results of an effective and efficient organizational structure, every organization must follow the sequence of the flow of the organization which includes the division of tasks, the formation of task units and the distribution of authority. With these sequences, the implementation of activities will be easier to control and the sequence of activities will be clear.

The placement of the Hamlet Head as the person in charge of each hamlet would make the work process easier because it was similar to the work structure system of the Hamlet Head in general. The placement of the head of the Neighborhood Associations and religious leaders as the party providing direct socialization also became added value because of their close and close communication with the community. In addition, the characteristic aspects of the figures also make it easier for emerging in the information conveyed. It indicates that the detailed division of tasks and prioritizing communication by human resources in accordance with the ability on the basis of work effectiveness has been taken into account by the Kalisidi Village Administration Staff in the organizing process. The fulfillment of these aspects was very important in organizing because in the process of cooperation it had to be determined who doing is, what doing is, who responsible is, for whom it is, the flow of communication relations and focusing the resources on the goal. In terms of process, the organization in the division of labor was divided into smaller jobs, assigning tasks according to the person's ability, allocating existing resources and coordinating them in order to effectively achieve organizational goals. (Fattah, 2008).

After planning and organizing had been carried out, then directing or actuating was the next step. In the directive function, every element of the team had carried out their duties properly and there was no difficulties encountered in the process of socializing the birth certificate ownership program. The success in the briefing process could not be separated from the organizing process that involved parties who are role models for the community culturally, administratively and religiously.

Based on Sillalahi (2011)the briefing process cannot be separated from the aspects of communication, leadership and motivation. These three aspects are very close and certainly have their own value, especially being dedicated to the progress of the community and Kalisidi Village. The process of implementing the socialization in Kalisidi Village was in accordance with the theory put forward by Silalahi. The socialization in the field was carried out directly by the Head of Neighborhood Associations and religious leaders and assisted by the Head of the Hamlet, Administrative Staff to the Village Head. The programs used for socialization were nyadran event, social gathering, Quranic recitation (tahlilan) and usual recitations. The socialization process ran and was accepted and responded well by the people. Based on the researchers, it is not an exaggeration because what provides socialization material is in accordance with the scope of the event used for socialization. The presence of the Head of the 
Neighborhood Association at social gathering events, religious leaders in every tahlilan to the Head of Neighborhood Association and religious leaders as well as the presence of village officials at the Nyadran and recitation events triggered the success of the socialization. The suitability of social position in aspects of life in society was the main key, moreover, the figures involved were the leaders in every event that were used for socialization.

Supervision based on Strong in Hasibuan (2009) control is a form of process in regulating various factors in a company in accordance with the conditions that have been planned. The controlling in activities was not difficult because each implementing team understood the important functions and values of birth certificates, even though they faced changing situations such as collisions with the implementation of regional and national elections, The activities can be easily controlled. Supervision or control of the optimization process based on the researchers was carried out directly and indirectly. Direct supervision was carried out with the direct presence of Kalisidi Village Administration Staff at the event which was used for socialization. Meanwhile, indirect supervision was carried out by communicating through communication media and checking the completeness of files submitted by the public.

The presence of the Village Administration Staff at the event which was used to disseminate the ownership of a birth certificate was carried out at the first time the socialization was carried out. It seemed to emphasize that the success of a socialization process started from the first time the socialization was carried out. By attending the socialization procession, the Village Administration Staff as village coordinator in the process of optimizing birth certificate ownership could find out how accurate the delivery of material is so that it can be understood by the people.
Furthermore, supervision was carried out through communication media based on the number of people who applied for ownership of birth certificates. If the community's response was still small, the Village Administration Staff would communicate with the Head of Hamlet, Neighborhood Association Heads and religious leaders regarding the obstacles found in the field. It then was able to find the initial problem from the small response of the community to take care of ownership of birth certificates independently by coming directly to the Department of Population and Civil Registration of Semarang Sub district. Meanwhile, indirect supervision through file checking was carried out when the community files had been collected by the Head of the Hamlet to the Village Office. Incomplete files would be reported to the head of the hamlet as well as asking about the problems related to incomplete files. Based on it, a solution can be found out to complete the file.

The explanation above indicates that the control or supervision process is carried out in detail and continuously. The supervisory function, which was accompanied by evaluation and solutions, made it easier to find out the obstacles experienced so that the next steps could be determined. Supervision carried out by the Village Administration Staff was in conformity with the stated theory of supervision procedures Hasbullah (2005) which states that supervision / control is an activity that must be carried out by a manager or leader in ensuring that each member has carried out activities that can bring the organization towards predetermined goals. Supervision that is carried out effectively can assist our efforts in completing the planned work and ensure that the implementation of the work can go in accordance with the existing plan. Therefore, the main objective of supervision was achieved, namely by making the goals that had been planned come true. Therefore, in order for the 
supervision system to be truly effective, meaning that it can realize its objectives, a surveillance system must at least immediately report any deviations from the plan (Manullang, 1982).

The Kalisidi Village Government's strategy in optimizing birth certificate ownership had been carried out in accordance with the management function. However, the results obtained at the beginning program did not match the expectations and were only able to generate public interest without any willingness to make certificate independently by coming to the Department of Population and Civil Registration of Semarang Regency individually.

The Implementing Team's unyielding spirit by conducting evaluations eventually found obstacles related to the distance and the livelihoods of Kalisidi Village people. Basedon (Hubeis and Najib, 2014) the strategic management activity processes consist of: 1) internal environmental analysis 2) external environment analysis 3) development of a clear vision and mission 4) setting goals and objectives 5) choosing the right strategy 6) determination of control. Of the six activity processes, activity number two became an obstacle which was then evaluated by the team which resulted in a change in strategy related to easy access for the community in making birth certificates.

Based on the explanation above, it can be seen that the strategy in optimizing birth certificate ownership was based more on the implementation of management functions supported by the implementation of strategic management. With this combination, not only the results of the evaluation were obtained but also the implementation of the solutions had been carried out.

\section{CONCLUSION}

Based on the results of research and discussion, the strategy of the village government in optimizing the achievement of birth certificate ownership was based on management functions in the form of planning, organizing, directing and controlling as well as being supported by strategic management. Planning began with the implementation of the program and then organizing was carried out by forming a team that involved related parties. Direction and control were carried out so that the team could work properly as predetermined goals. In strategic management, the internal environmental analysis became an obstacle in optimizing birth certificates. Through the management function ,the obstacles could be evaluated so that it could produce an easier and better strategy so that it can be implemented for further activities.

\section{BIBLIOGRAPHY}

Sundari, A. (2011). Manajemen Berbasis Sekolah di Era Otonomi Pendidikan. Universitas Lampung.

Bailah. (2019). Pengelolahan Adimintrasi Penduduk Desa. Penerbit Uwais Insipirasi Indonesia.

Maksudi, B.I. (2017). Dasar - dasar Adminstrasi Publik Dari Klasik ke kontemporer. PT Rajagrafindo Persada.

Terry, G.R.. (2014). Prinisip - Prinsip Manajemen. Penerbit Bumi Aksara.

Hasbullah. (2005). Dasar - dasar Ilmu Pendidikan. PT Bumi Aksara.

Irham Fahmi. (2014). Manajemen Strategis Teori dan Aplikasi. Penerbit Alfabeta.

Manullang, M.. (1982). Dasar - dasar Manajemen. Penerbit Ghalia Indonesia.

Malayu S. P. Hasibuan. (2009). Manajemen Sumber Daya Manusia. PT Bumi Aksara.

Munir, S. (2017). Puluhan Ribu Anak di Kabupaten Semarang Belum Punya Akta Kelahiran. Kompas.com. Semarang. 9 Januari.

Hubeis, M., dan Najib, M. (2014). Manajemen Strategik Dalam Pengembangan Daya Saing Organisasi. PT Elex Media Komputindo.

Fattah, N. (2008). Landasan Manajemen Pendidikan. Penerbit Remaja Rosdakarya.

Nippi, A.T., \& M, A. P. (n.d.). Kelompok Tani (Studi Kasus Di Desa Siawung Kecamatan Barru Kabupaten Barru). 2(1), 35-47.

Pelayanan, O., (2019), Kependudukan, A., Kependudukan, D., Pencatatan, D. A. N., \& Kabupaten, S. Nusantara Journal of Economics (NJE). 01(02). 
Tri Wida Yanti, Arief Sadjiarto \& Destri Sambara Sitorus, Strategies to Achieve Birth Certificate

Ramadhan, N.Y., Muchsin, S., \& Widodo, R. P. (2019). Kota Cirebon Dalam Pelayanan Pembuatan Akta Kelahiran (Studi Pada Dinas Kependudukan dan Pencatatan Sipil Kota Cirebon , Provinsi Jawa Barat ). 13(6), 39-45.

Sedarmayanti. (2014). Manajemen Strategi. PT Reffika Aditama.
Wiludjeng, S. (2007). Pengantar Manajemen. Penerbit Graha Ilmu.

Handoko, T.H. (2014). Manajemen. Penerbit BPFE.

Sillalahi, U. (2011). Asas - Asas Manajemen. PT Reffika Aditama.

Law No. 23 Article 59 of 2006 